\title{
OMD wt Allele
}

National Cancer Institute

\section{Source}

National Cancer Institute. OMD wt Allele. NCI Thesaurus. Code C97681.

Human OMD wild-type allele is located in the vicinity of $9 q 22.31$ and is approximately 10 $\mathrm{kb}$ in length. This allele, which encodes osteomodulin protein, plays a role in the modulation of cell adhesion. Mutation of the gene may be associated with ovarian serous carcinoma. 